Nowoczesne Systemy Zarządzania

Zeszyt 12 (2017), nr 1 (styczeń-marzec)

ISSN 1896-9380, s. 105-117

Modern Management Systems

Volume 12 (2017), No. 1 (January-March)

ISSN 1896-9380, pp. 105-117

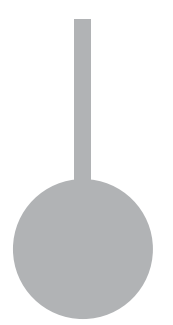

Instytut Organizacji i Zarządzania

Wydział Cybernetyki

Wojskowa Akademia Techniczna

w Warszawie

Institute of Organization and Management

Faculty of Cybernetics

Military University of Technology

\title{
Determinants of human resource management in health care institutions
}

\section{Determinanty zarządzania zasobami ludzkimi w instytucjach opieki zdrowotnej}

\author{
Paulina Ucieklak-Jeż \\ Jan Dlugosz University in Czestochowa, \\ Faculty of Philology and History \\ e-mail: p.ucieklak@o2.pl \\ Agnieszka Bem \\ Wroclaw University of Economics \\ Department of Corporate Finance and Public Finance
}

Abstract: The aim of the paper is to present specific conditioning of a personal function in health care's institutions, hospitals in the first place. Detailed hypotheses have been formulated as follow:

- $\quad$ there are specific legal determinants of human resource management in health care units,

- there are specific demographic determinants of human resource management in health care units,

- there are specific economic determinants of human resource management in health care units.

Research carried out in this area clearly indicate, that the approach to the personal function is different in hospitals that have undergone a restructuring process and in hospitals that haven't launched any restructuring program.

Keywords: health care, Human Resources for Health (HRH), human resource management in health care

Abstrakt: Celem niniejszej pracy jest prezentacja podstawowych problemów, związanych z zarządzaniem zasobami ludzkimi w szpitalach. Szczegółowe hipotezy zostały sformułowane następująco:

- $\quad$ istnieją szczególne uwarunkowania prawne zarządzania zasobami ludzkimi w zakładach opieki zdrowotnej,

- $\quad$ istnieją szczególne uwarunkowania demograficzne zarządzania zasobami ludzkimi w zakładach opieki zdrowotnej,

- $\quad$ istnieją szczególne uwarunkowania ekonomiczne zarządzania zasobami ludzkimi w zakładach opieki zdrowotnej.

Badania prowadzone w tym obszarze jasno wskazują, że podejście do funkcji personalnej jest różne w jednostkach, które przeszły restrukturyzację i w jednostkach, które takiej restrukturyzacji nie przeszły. 
Słowa kluczowe: opieka zdrowotna, zasoby ludzkie systemu zdrowotnego, zarządzanie zasobami ludzkimi w służbie zdrowia

\section{Introduction}

Human resources are one of the most important resources, which lead to effective performance in the health care system. According to WHO studies, medical services of high quality can be ensured only through a combination of various types of resources (physical, financial), including human ones (Zybała, 2009).

The International Labour Organisation defines Human Resources for Health (HRH) using two approaches, which we may called as "narrow" and "wide"1. In the "narrow" approach, human resources means medical staff employed in healthcare sector, and in the "wide" sense - all people working in healthcare, which also include a personnel working in administrative institutions, insurance companies, as well as learning and training's units (Zybała, 2009).

Effective management of working teams affects significantly the quality of services provided by health care units. According to that, this paper presents problems concerning issues related to the management of human resources in hospitals. Authors show the specific determinants of personal functions in health care sector's institutions (Ucieklak-Jeż, Bem, 2015, pp. 28-48).

\section{The objectives of research and the research hypothesis}

The aim of the paper is to present specific conditioning of a personal function in health care's institutions, hospitals in the first place. Authors also formulate practical proposals, which could be used to define human resource management in health care and indicate a clear problem arising out of the specific circumstances of personal functions in health care. The research question has been put: what causes special character of human resources management in health care sector?

To answer this question precisely, the following specific problems have been formulated:

- what are the legal conditioning, that may affect human resources management in health care units?

- what are the demographic conditioning, that may affect human resources management in health care units?

- what are the economic conditioning, that may affect human resources management in health care units?

1 Terms of employment and working conditions in health sector reform, International Labour Organisation, Geneva 1999. 
The next stage of research procedure is to formulate hypotheses:

The main hypothesis: there are specific determinants of human resource management in health care units.

Detailed hypotheses have been formulated as follow:

- there are specific legal determinants of human resource management in health care units,

- there are specific demographic determinants of human resource management in health care units,

- there are specific economic determinants of human resource management in health care units.

\section{Legal determinants of human resource management in health care units}

R. W. Griffin specifies, that management means an accurate understanding of what you expect from people, and then ensure, that they are in the best and cheapest way to do it (Armstrong, 1998). According to H. Bieniok, human resource management is making decisions, and later, efforts to make effective use of human potential, and thanks to that - the efficient use of other resources, in order to ensure a competitive advantage and long-term growth, while meeting the needs and aspirations of employees (Bieniok, 2006, p. 14). R. Armstrong indicate, that human resource management is a strategic and coherent approach to management of the most valuable assets of the organization, that is to say, people employed who individually and collectively contribute to the achievement of enterprise's objective (Armstrong, 1998). H. T. Graham and R. Bennett state, that the aim of human resources management is to ensure that company employees (human resources) are used in order to achieve use their potential (capabilities), and ensure employees getting both material and psychological rewards from their work (Graham, Bennett, 1995). M. Adamiec, B. Kożusznik define human resource management as a kind of strategy and practice of acquisition, use (use), development and maintenance of people their capacities and skills - in the organization (Adamiec, Kożusznik, 2008, p. 18). The notion of human resource management has been disseminated on the basis of American literature, and then, transferred to business practices. It means strategic, coherent and comprehensive approach to the management of people, who are the most precious resource of the organization. It is set on integration of the most important objectives of the organization with the objectives of each employee, arising from its needs (Zając, 2007, pp. 13-14). A. Pocztowski calls for the strategic integration of personal affairs and business matters, an active role line management in resolving personal issues, and identifies the need to structure a company culture, integration 
of personal processes and building of employee's involvement, as tools to achieve company's objectives (Ozcan, Hornby, 1999, pp. 210-220), (Zając, 2007, pp. 13-14).

Human resources are of crucial importance in the context of quality and patient's satisfaction, and so, indirectly, in building hospital's reputation. The medical professions are, however, a certain degree of specificity, resulting from legislation, which define strict rules. Human resources management in health care units takes place in specific conditions arising from external circumstances, based especially on character of curative activity. Regulations implemented by the NFZ and the Ministry of Health directly affect the need for health professionals (doctors, nurses, other staff), including both amount of employees, as well as their structure and qualifications. From the point of view of human resources management in hospitals, regulations related to medical professions play also very important role. It concerns doctors, nurses, midwives, pharmacists, paramedics, laboratory technicians or feldshers. The rules govern not only scope for these professions, but also questions the eligibility to exercise medical professions or the need for vocational courses. Execution of many medical occupation is linked to mandatory membership in professional self-government, what strongly affects work, through occupational supervision, creation of standards, including ethical ones (Karkowski, 2012).

\section{The demographic determinants of human resource management}

Demographic factors, such as the strength and structure of population by age, working-age population, internal and external migration and urbanization's level, impact on the demand and supply side of the labour market, setting consequently an important variable of the process of human resources management (Pocztowski, 2003, pp. 34-39).

The primary indicator of human resources in health care is the number of doctors per defined share of population (usually 10,000 or 100,000). The share of doctors per 1,000 residents include doctors and medical specialists practicing in the public and private sector, with the exception of doctors working outside the country, in administration, in research institution and industry, but taking into account the foreign doctors practicing within the country (GUS, 2010).

It is worth noting that Polish health units, primarily hospitals, work in terms of a shortage of workers on the labour market. The analysis of available resources (table 1. indicates that shortages do not concern, or at least not to the same extent, of all groups of workers. The number of primary care doctors, midwives and pharmacists in Poland is comparable to other countries of Europe. The number of medical specialists is one of the lowest in Europe - this also applies to nurses and dentists. By far the worst situation is observed in case of physical therapists. 
Table 1. Number of active medical professionals per 1,000 inhabitants

\begin{tabular}{|c|c|c|c|c|c|c|c|}
\hline & \multicolumn{7}{|c|}{ Number of active medical professionals per 1,000 habitants } \\
\hline & $\begin{array}{c}\text { primary } \\
\text { care } \\
\text { doctors }\end{array}$ & specialists & midwives & nurses & dentists & pharmacists & physiotherapists \\
\hline Austria & 0.78 & 2.42 & 0.16 & 7.76 & 0.56 & 0.68 & 0.38 \\
\hline Belgium & 1.11 & 1.76 & & 9.32 & 0.7 & 1.16 & 1.66 \\
\hline $\begin{array}{c}\text { Czech } \\
\text { Republic }\end{array}$ & 0.7 & 2.88 & 0.43 & 8.03 & 0.71 & 0.59 & 0.73 \\
\hline Estonia & 1.56 & 2.17 & 0.29 & 6.24 & 0.89 & 0.63 & 0.23 \\
\hline Finland & 0.66 & 1.45 & 0.41 & 10.45 & 0.72 & 1.11 & 2.03 \\
\hline France & 0.3 & 1.74 & 0.3 & & 0.64 & 1.06 & 1.15 \\
\hline Germany & 0.58 & 2.22 & 0.23 & 11.31 & 0.8 & 0.62 & 1.42 \\
\hline Hungary & 0.61 & .. & 0.18 & 6.21 & 0.53 & 0.58 & 0.3 \\
\hline Island & 0.78 & 2.19 & 0.87 & 14.82 & 0.89 & 1.19 & 1.47 \\
\hline Italy & 0.59 & .. & & & & & 0.85 \\
\hline Luxembourg & .. & 1.95 & 0.36 & 11.27 & 0.84 & 0.72 & 1.66 \\
\hline Netherland & 0.2 & 1.74 & 0.16 & .. & & 0.21 & 0.95 \\
\hline Norway & 0.45 & 1.71 & 0.54 & 16.4 & 0.88 & 0.65 & 0.57 \\
\hline Poland & 0.74 & 1.78 & 0.59 & 5.21 & 0.34 & 0.68 & 0.13 \\
\hline Portugal & 0.63 & 2.05 & & & & 0.75 & 0.32 \\
\hline Slovakia & 0.56 & .. & & & & & 0.49 \\
\hline Slovenia & 0.81 & 1.91 & 0.05 & 8.33 & 0.62 & 0.55 & \\
\hline Spain & 0.3 & 2.31 & & 5.22 & & 0.94 & 0.8 \\
\hline Sweden & 0.63 & 2.1 & 0.74 & & 0.8 & 0.77 & 1.25 \\
\hline Switzerland & 1.06 & 2.16 & 0.29 & 16.6 & 0.52 & 0.53 & \\
\hline UK & 0.81 & 1.94 & 0.49 & 7.99 & 0.53 & 0.76 & 0.43 \\
\hline
\end{tabular}


One of the sources of this situation may be less relatively low number of medical graduates in Poland - one of the lowest in Europe in case of doctors. In the case of other medical professions number of graduates does not differ from the average of other countries (although e.g. in Slovenia the number of nursing graduates is almost double) (table 2).

Table 2. Number of graduates per 100,000 inhabitants

\begin{tabular}{|c|c|c|c|c|c|}
\hline \multicolumn{7}{|c|}{ Graduates per 100,000 habitants } \\
\hline & medicine & stomatology & pharmacy & midwifery & nursing \\
\hline Austria & 19.62 & 1.50 & 2.74 & 0.58 & 57.26 \\
\hline Belgium & 10.18 & 1.32 & 4.58 & 3.87 & 37.47 \\
\hline Czech Republic & 13.91 & 2.86 & 3.27 & 2.50 & 17.36 \\
\hline Estonia & 9.42 & 2.34 & 5.88 & 4.44 & 34.35 \\
\hline Finland & 11.53 & 2.56 & 8.04 & 3.19 & 63.66 \\
\hline France & 8.67 & 1.59 & 3.72 & 1.41 & 35.49 \\
\hline Germany & 11.7 & 2.67 & 2.28 & 0.77 & 27.62 \\
\hline Hungary & 11.51 & 2.8 & 2.75 & 0.42 & 25.51 \\
\hline Island & 13.79 & 1.88 & 5.02 & 3.76 & 65.20 \\
\hline Italy & 11.28 & 2.2 & 4.52 & 1.43 & 19.18 \\
\hline Luxembourg & 8.02 &.. &.. & 0.77 & 25.08 \\
\hline Netherland & 14.55 & 1.67 & 1.14 & 0.84 & 38.70 \\
\hline Norway & 11.47 & 2.73 & 2.14 & 2.06 & 67.57 \\
\hline Poland & $\mathbf{8 . 6 9}$ & $\mathbf{2 . 4 9}$ & $\mathbf{3 . 3 7}$ & $\mathbf{5 . 7 4}$ & $\mathbf{4 4 . 9 5}$ \\
\hline Portugal & 12.19 & 6.85 & 11.11 &.. & 32.12 \\
\hline Slovakia & 10.93 & 1.46 & 5.22 & 1.26 & 58.52 \\
\hline Slovenia & 10.03 & 1.85 & 6.43 & 0.97 & 81.79 \\
\hline Spain & 8.98 & 2.98 & 5.09 &.. & 24.93 \\
\hline Switzerland & 9.4 & 1.31 & 2.05 & 0.80 & 78.11 \\
\hline UK & 11.43 &.. &.. & 2.52 & 34.15 \\
\hline & & & & & \\
\hline & & & & & \\
\hline
\end{tabular}

Source: own study on OECD data 
Another issue affecting, potentially, staffing shortages is a relatively large number of hospital beds in Poland and large employment of workers per one bed (table 3). This does not apply to nursing staff, where the employment rate per 1 is the lowest in Europe.

Table 3. The number of hospital beds per 1,000 inhabitants employed in hospitals for 1 bed

\begin{tabular}{|c|c|c|c|}
\hline & $\begin{array}{c}\text { number of hospital beds } \\
\text { per } 1,000 \text { inhabitants }\end{array}$ & $\begin{array}{l}\text { Employed in hospitals } \\
\text { per one hospital beds }\end{array}$ & $\begin{array}{c}\text { Nurses employed per } \\
1 \text { hospital bed }\end{array}$ \\
\hline Austria & 7.66 & 1.70 & .. \\
\hline Belgium & 6.35 & 2.76 & 1.13 \\
\hline Czech Republic & 6.84 & 2.01 & 0.8 \\
\hline Estonia & 5.36 & 2.65 & 0.83 \\
\hline Finland & 5.52 & 3.27 & 1.25 \\
\hline France & 6.36 & 3.14 & 0.90 \\
\hline Germany & 8.22 & 8.34 & 0.84 \\
\hline Hungary & 7.19 & 1.43 & 0.49 \\
\hline Island & 3.31 & 7.75 & 3.06 \\
\hline Ireland & 2.95 & 4.31 & 1.78 \\
\hline Italy & 3.52 & 3.40 & 1.31 \\
\hline Luxembourg & 5.28 & 5.15 & .. \\
\hline Norway & 4.19 & 3.97 & 2.24 \\
\hline Poland & 6.55 & 6.52 & 0.54 \\
\hline Portugal & 3.37 & 3.39 & 1.05 \\
\hline Slovenia & 4.62 & 2.26 & 0.94 \\
\hline Spain & 3.05 & 3.8 & 1.05 \\
\hline Sweden & 2.71 & 2.62 & .. \\
\hline Switzerland & 4.87 & 4.82 & 1.67 \\
\hline UK & 2.88 & 7.56 & .. \\
\hline
\end{tabular}

Source: own study on OECD data 
The structure of medical specialization, among which dominate surgical, internal medicine and family medicine specialization (table 4) is a separate issue. It does not correspond to really human resource needs - shortages concern oncologists, endocrinologists and nursing staff. Some specializations are nationally scarce, and changing legal requirements deepen this deficit.

Table 4. The structure of medical specialization in Poland

\begin{tabular}{|c|c|}
\hline Anaesthesiology and intensive therapy & $5.8 \%$ \\
\hline Surgery & $14.4 \%$ \\
\hline Pulmonology & $2.4 \%$ \\
\hline Internal diseases & $12.8 \%$ \\
\hline Dermatology and Venereology & $1.6 \%$ \\
\hline Cardiology & $3.5 \%$ \\
\hline Family medicine & $11.1 \%$ \\
\hline Occupational medicine & $1.4 \%$ \\
\hline Neurology & $4.1 \%$ \\
\hline Ophthalmology & $3.3 \%$ \\
\hline Oncology & $0.8 \%$ \\
\hline Otolaryngology & $2.3 \%$ \\
\hline Paediatrics & $5.5 \%$ \\
\hline Obstetrics and gynaecology & $6.7 \%$ \\
\hline Psychiatry & $4.0 \%$ \\
\hline Radiology & $3.9 \%$ \\
\hline
\end{tabular}

Source: own elaboration based on Health and health care in 2012, GUS, 2013

Survey indicates, that, in the opinion of directors, the biggest needs concern the employment of (IBC Group Central Europe Holding S.A., 2011): internists, anesthesiologists, emergency medicine doctors, general surgeons, psychiatrists, pediatricians, neonatologists, neurologists, cardiologists, physicians, orthopaedic, rehabilitation experts. In the opinion of head doctors the greatest needs involve (IBC Group Central Europe Holding S.A., 2011): physicians, internists, pediatricians, anesthesiologists. 


\section{Economic determinants of human resource management in health care units}

To economic conditions affecting the implementation of the various human resources management's tasks several determinants should be included: the existing economic system, economic and market situation, competition and the performance of the labour market (Pocztowski, 2003, pp. 34-39).

Wages are a major component of costs in hospitals. The media often provide contradictory information on doctor's remunerations and false beliefs about low wages are still present, which, in the light of certain opinions, may be the cause of low-quality work. Tables 5 and 6 present data on the remuneration of primary care doctors and specialists in chosen European countries. Comparisons are based on the PPP USD, in relation to the average salary and to GDP per capita.

Table 5. Remuneration of general practitioners employed in full-time

\begin{tabular}{|c|c|c|c|}
\hline \multicolumn{5}{|c|}{ Remuneration of employed primary care doctors } \\
\hline & PPP USD & in relation to the average wage & in relation to GDP p.c. \\
\hline Denmark & 133810.6 & 2.58 & 3.13 \\
\hline Estonia & 33431.85 & 1.59 & 1.36 \\
\hline Finland & 78663.88 & 1.77 & 2.01 \\
\hline Hungary & 30830.06 & 1.32 & 1.36 \\
\hline Island & 97841.07 & $\ldots$ & 2.50 \\
\hline Luxembourg & 204555.8 & 3.48 & 2.51 \\
\hline Netherland & 92567.85 & 1.92 & 2.15 \\
\hline Poland & 46697.84 & $\ldots$ & 2.12 \\
\hline Slovakia & 39174.64 & 1.70 & 1.8 \\
\hline Slovenia & 81760.62 & 2.26 & 2.94 \\
\hline Spain & 84155.69 & 2.21 & 2.48 \\
\hline UK & 81357.76 & 1.82 & 2.34 \\
\hline
\end{tabular}

Source: own elaboration based on OECD data 
Data show that earnings of doctors in Poland still differ from the earnings of doctors in Europe, particularly in case of professionals. However, several important reservations should be expressed. Data presented above apply to all doctors, also working on a contract, and not only employed in hospitals, but also in small health centres. Data do not also contain additional income related with, for example night duties in hospitals, which are extra paid.

Table 6. Remuneration of medical specialists employed in full-time

\begin{tabular}{|c|c|c|c|}
\hline \multicolumn{4}{|c|}{ Remuneration of medical specialists } \\
\hline & PPP USD & in relation to the average wage & in relation to GDP p.c. \\
\hline Czech Republic & 50697.84 & 2.16 & 1.84 \\
\hline Dania & 133810.55 & 2.60 & 3.13 \\
\hline Estonia & 45619.24 & 2.08 & 1.86 \\
\hline Finland & 113575.4 & 2.58 & 2.90 \\
\hline France & 88087.14 & .. & 2.42 \\
\hline Greece & 73008.78 & 2.47 & 2.81 \\
\hline Hungary & 42708.59 & 1.77 & 1.89 \\
\hline Island & 99474.88 & .. & 2.54 \\
\hline Ireland & 216735.06 & 3.62 & 4.94 \\
\hline Italy & 95124.89 & 2.51 & 2.72 \\
\hline Luxembourg & 219871.09 & 3.69 & 2.46 \\
\hline Netherland & 146751.32 & 3.04 & 3.4 \\
\hline Norway & 93523.04 & 1.76 & 1.41 \\
\hline Poland & 36546.11 & 1.57 & 1.6 \\
\hline Slovenia & 85412.31 & 2.29 & 3 \\
\hline Spain & 91566.4 & 2.33 & 2.85 \\
\hline UK & 112867.86 & 2.43 & 3.18 \\
\hline
\end{tabular}

Source: own elaboration based on OECD data 
The analysis of nursing personnel's remunerations based on purchasing power parity ranks nursing staff's salaries at the same level as in neighbouring countries, however, in relation to the average wage and in relation to GDP per capita are lower than in other European countries (table 7).

Table 7. Salary of nurses employed in full time

\begin{tabular}{|c|c|c|c|}
\hline \multicolumn{5}{|c|}{ Remuneration of employed nurses } \\
\hline & PPP USD & in relation to the average wage & in relation to GDP p.c. \\
\hline Denmark & 56584.15 & 1.10 & 1.32 \\
\hline $\begin{array}{c}\text { Czech } \\
\text { Republic }\end{array}$ & 24324.54 & 1.04 & 0.88 \\
\hline Estonia & 20233.2 & 0.92 & 0.82 \\
\hline Finland & 41552.35 & 0.95 & 1.06 \\
\hline Hungary & 19321.01 & 0.80 & 0.85 \\
\hline Island & 44327.22 &. & 1.13 \\
\hline Luxembourg & 86885.97 & 1.46 & 0.97 \\
\hline Netherland & 48117.53 & 1.00 & 1.12 \\
\hline Poland & $\mathbf{2 4 1 0 4 . 4 6}$ & $\mathbf{1 . 0 3}$ & $\mathbf{1 . 0 6}$ \\
\hline Norway & 55296.81 & 1.04 & 0.84 \\
\hline Slovenia & 35958.89 & 0.97 & 1.26 \\
\hline Spain & 48331.56 & 1.23 & 1.50 \\
\hline UK & 48977.37 & 1.06 & 1.38 \\
\hline
\end{tabular}

Source: own elaboration based on Eurostat data

In the situation of personnel's shortage, hospitals compete among themselves, first and foremost, in remuneration's level. That's way, from the point of view of employers, keeping key employees is a big problem. At the same time, it should be noted, that staff costs are very important component of hospital's total cost.

The contract value creates hospital's budgetary restrictions. Hospitals have a very limited ability to adjust labour costs to reduced financing and possibilities to increase revenues are virtually none. Relatively short horizon of signing, from the point of view of human resources management, impedes effective implementation of the personnel function in the long term. 


\section{Conclusions}

Polish hospitals usually have less inflexible personnel's systems and organizational culture than companies of similar size. Most hospitals do not have any human management's strategy and stability of employment and personnel policy is close to classical administration, rather than a modern human resources management. Systems of remuneration and incentive schemes are usually not efficient (Pocztowski, 2003, pp. 34-39).

It seems that the biggest challenge for health units (mainly hospitals), is personnel's selection. The process of service's provision depends, to a large extent, on the labour organization, good management and motivating systems. A key problem, however, is the acquisition of skilled personnel, to ensure the efficient provision of high-quality benefits. This is of particular importance in the context of demographic change, which will result in an increased demand for health services (Mcbride, Hyde, 2011, pp. 299-318).

Decisions shaping employment's structure are strongly influenced by the value of contract with National Health Fund, but even its reduction does not usually equal decisions involving job-cuts, in the context of diminishing highly skilled human resources. In terms of recruitment, particularly in the area of required qualifications, a big role play legal regulations, especially concerning a minimal level of qualifications.

Surveys show, that directors of hospitals passively extrapolate current trends in employment's structure in their units. It's primarily manifested in low interest in employment of specialists in geriatrics, oncology, epidemiology, which indicates the lack of prediction of future trend and potential changes of the demographic structure.

Components of the personal function, in case of health care institutions, are exactly the same as in any other company. However, character of medical business forces adaptation to requirements, arising, for example, form strict rules regulating medical professions.

Research carried out in this area clearly indicate, that the approach to the personal function is different in hospitals that have undergone a restructuring process and in hospitals that haven't launched any restructuring program. Restructured hospital perform the personal function, including personnel selection or employee assessment, in relatively more modern way.

\section{BIBLIOGRAPHY}

[1] Adamiec M., Kożusznik B., 2008, Zarządzanie zasobami ludzkimi, AE, Katowice.

[2] Armstrong M., 1998, Zarzadzanie zasobami ludzkimi, Wydawnictwo Profesjonalnej Szkoły Biznesu, Kraków.

[3] BIENioK H., 2006, System zarządzania zasobami ludzkimi przedsiębiorstwa, AE, Katowice.

[4] Podstawowe dane z zakresu ochrony zdrowia w 2009 r., 2010, Główny Urząd Statystyczny, Warszawa. 
[5] Graham H. T., Bennett R., 1995, Human Resources Management 8th Edition, The M., E. Handbook Series, London.

[6] IBC Group Central Europe Holding S.A., 2011, Analiza potrzeb szkoleniowych personelu medycznego oraz pracowników wykonujących zawody niemedyczne w ramach systemu opieki zdrowotnej $w$ Polsce. Badanie ewaluacyjne zrealizowane na zlecenie Ministerstwa Zdrowia.

[7] Karkowski T., 2012, Restrukturyzacja szpitali, Wolters Kluwer Polska Sp. z o.o., Warszawa.

[8] Mcbride A., Hyde P., 2011, Zarządzanie zasobami ludzkimi w opiece zdrowotnej, [in:] K. Walshe i J. Smith (eds.), Zarządzanie w opiece zdrowotnej, Wolters Kluwer Polska Sp. z o.o., Warszawa.

[9] Ozcan S., Hornby P., 1999, Determining Hospital Workforce Requirements: A case study. Human Resources for Health Development Journal (3).

[10] Pocztowski A., 2003, Zarzązanie zasobami ludzkimi, PWN, Warszawa.

[11] UcieKLAK-Jeż P., Bem A., 2015, Rola zasobów ludzkich w ochronie zdrowia, [in:] R. Balcerzyk, A. Bem, W. Karna, A. Kożuch, B. Kożuch, I. Marzec, P. Ucieklak-Jeż, Zarządzanie zasobami ludzkimi w administracji samorządowej, Wydawnictwo Wyższa Szkoła Oficerska Wojsk Lądowych im. gen. Tadeusza Kościuszki, Wrocław.

[12] ZająC C., 2007, Zarządzanie zasobami ludzkimi, Wydawnictwo Wyższej Szkoły Bankowej, Poznań.

[13] ZүваєA A., 2009, Wyzwania w systemie ochrony zdrowia - zasoby ludzkie i zasoby organizacyjne w centralnych instytucjach, Krajowa Szkoła Administracji Publicznej, Warszawa. 